This item was submitted to Loughborough's Research Repository by the author.

Items in Figshare are protected by copyright, with all rights reserved, unless otherwise indicated.

\title{
A cyclone climatology of the British-Irish Isles 1871-2012
}

\section{PLEASE CITE THE PUBLISHED VERSION}

http://dx.doi.org/10.1002/joc.4425

\section{PUBLISHER}

Wiley / @ Royal Meteorological Society

\section{VERSION}

AM (Accepted Manuscript)

\section{PUBLISHER STATEMENT}

This work is made available according to the conditions of the Creative Commons Attribution-NonCommercialNoDerivatives 4.0 International (CC BY-NC-ND 4.0) licence. Full details of this licence are available at: https://creativecommons.org/licenses/by-nc-nd/4.0/

\section{LICENCE}

CC BY-NC-ND 4.0

\section{REPOSITORY RECORD}

Matthews, Tom, Conor Murphy, Robert Wilby, and Shaun Harrigan. 2015. "A Cyclone Climatology of the British-irish Isles 1871-2012". Loughborough University. https://hdl.handle.net/2134/18342. 


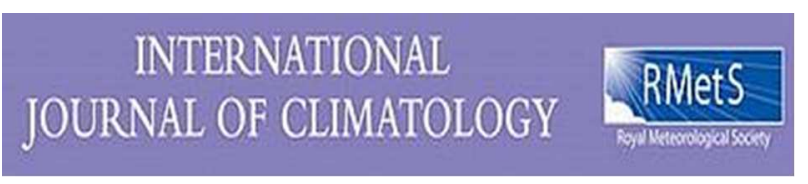

\section{A cyclone climatology of the British-Irish Isles 1871-2012}

\begin{tabular}{|r|l|}
\hline Journal: & International Journal of Climatology \\
\hline Manuscript ID: & JOC-14-0719.R1 \\
\hline Wiley - Manuscript type: & Research Article \\
\hline Date Submitted by the Author: & n/a \\
\hline Keyworde List of Authors: & $\begin{array}{l}\text { Matthews, Tom; National University of Ireland Maynooth, Geography } \\
\text { Murphy, Conor; Maynooth University, Geography; National University of } \\
\text { Ireland Maynooth, Geography } \\
\text { Wilby, Rob; Loughborough University, Geography } \\
\text { Harrigan, Shaun; Maynooth University, Geography; National University of } \\
\text { Ireland Maynooth, Geography }\end{array}$ \\
\hline \multicolumn{2}{|c|}{\begin{tabular}{l} 
Cyclane, Storm, 20th Century Reanalysis, North Atlantic storm track, North \\
\hline
\end{tabular}} \\
\hline
\end{tabular}

SCHOLARONE ${ }^{m}$

Manuscripts 
British-Irish Isles cyclone climatology

$3 \quad{ }^{1}$ Irish Climate Analysis and Research Units (ICARUS), Department of Geography, National

$4 \quad$ University of Ireland Maynooth, Republic of Ireland

$5 \quad{ }^{2}$ Department of Geography, Loughborough University, UK

\section{A cyclone climatology of the British-Irish Isles 1871-2012}

\author{
Matthews ${ }^{1} \mathrm{~T}$, Murphy $^{1} \mathrm{C}$, Wilby $^{2} \mathrm{RL}, \operatorname{Harrigan}^{1} \mathrm{~S}$
}

\section{Abstract}

7 The British-Irish Isles (BI) lie beneath the North Atlantic storm track year-round and thus are 8 impacted by the passage of extra-tropical cyclones. Given recent extreme storminess and 9 projections of enhanced winter cyclone activity for this region, there is much interest in 10 assessing the extent to which the cyclone climate of the region may be changing. We address 11 this by assessing a 142-year (1871-2012) record of cyclone frequency, intensity and 12 'storminess' derived from the $20 \mathrm{CR}$ dataset. We also use this long-term record to examine 13 associations between cyclone activity and regional hydroclimate. Our results confirm the 14 importance of cyclone frequency in driving seasonal precipitation totals which we find to be 15 greatest during summer months. Cyclone frequency and storminess are characterised by 16 pronounced inter-annual and multi-decadal variability which are strongly coupled to 17 atmospheric blocking in the Euro-Atlantic region, but we detect no evidence of an increasing trend. We observe an upward trend in cyclone intensity for the BI region, which is strongest in winter and consistent with model projections, but promote caution interpreting this given the changing data quality in the $20 \mathrm{CR}$ over time. Nonetheless, we assert that long-term reconstruction is helpful for contextualising recent storminess and for identifying emerging changes in regional hydroclimate linked to cyclones.

Key words: cyclone; storm; $20^{\text {th }}$ Century Reanalysis; North Atlantic storm track; North

24 Atlantic Oscillation; British-Irish Isles precipitation

\section{Corresponding author:}

Tom Matthews, Irish Climate Analysis and Research Units (ICARUS), Department of 
British-Irish Isles cyclone climatology

\section{Introduction}

Extra-tropical cyclones are of tremendous physical and societal importance due to their role in redistributing heat, moisture and momentum between latitudes and the extreme surface weather events associated with their passing. The climatological significance of cyclones (or 'storms') is particularly apparent for the British-Irish Isles (BI) as the North Atlantic storm track crosses these densely-populated islands year-round (Woolings, 2010). Producing longterm cyclone climatologies for this region has, therefore, attracted attention from the research community (e.g. Sweeney, 2000; Hickey, 2003, 2011; Hanna et al., 2008; Allan et al., 2009; Cornes and Jones, 2011), not least because this area of the North Atlantic is projected to experience enhanced winter cyclone activity as the climate warms (Woolings et al., 2012; Collins et al., 2013; Feser et al., 2014 and references therein). Long-series of observed cyclonicity provide a means to contextualize apparently 'extreme' seasonal storminess (e.g. Blackburn et al., 2008; Dong et al., 2013a; Matthews et al., 2014) as well as to benchmark emerging trends.

Some long-term cyclone climatologies for Europe and/or the BI have used extreme wind speeds as a proxy for storminess, derived from direct surface observations (e.g. Sweeney, 2000; Hickey 2003, 2011) or geostrophic principles applied to air pressure records (Alexandersson et al., 1998, 2000; Matulla et al., 2008; Wang et al., 2009; Cornes and Jones, 2011). Others have scrutinized high-frequency air pressure variability (Hanna et al., 2008; Allan et al., 2009), or have used tide gauge data (Woodworth and Blackman, 2002; Vilibic and Sepic, 2010; Esteves et al., 2011) to assess historic storminess. Thus, existing work has relied largely upon in-situ measurements from long-running weather/oceanographic stations to serve as a proxy for cyclone frequency and intensity. Feature identification/tracking algorithms which detect cyclones from gridded pressure fields offer scope for identifying and characterising cyclones explicitly. Such techniques have yielded cyclone climatologies of the North Atlantic and beyond (Simmonds and Keay, 2000; Wang et al., 2006; Raible et al., 2008), but have rarely been used to gain insight into the cyclone climatology of the BI in particular. Historically, this is explained by the brevity of reanalysis products ( $\sim 50$ years) compared with station data.

However, the advent of the 20th Century Reanalysis V2 dataset (hereafter 20CR: Compo et al., 2011), permits storm reconstruction back to the 1870s. For example, Wang et al. (2013) used the 20CR to identify cyclones over the extra-tropics in both hemispheres, whilst Jones et 
British-Irish Isles cyclone climatology

62 al. (2013) used this dataset to produce an objective catalogue of Lamb Weather Types (LWTs) 63 for the BI. In addition, Wang et al. (2014) presented a 'Cyclone Activity Index' (defined in 64 Section 4), and a time series of extreme wind speeds for the North Sea region. Despite the 65 potential that $20 \mathrm{CR}$ offers for providing insights into long-term cyclone characteristics 66 (Cornes, 2014) it has not yet been used to construct a cyclone climatology for the BI. We 67 address this gap and seek to complement and extend long-running storminess metrics 68 provided by station-based methods.

\section{Aims and Objectives}

70 Our main aim is to derive a long-term cyclone record for the BI based on 20CR. Our 71 objectives are to 1) establish the seasonal climatology of cyclones over the region, including 72 their influence on precipitation totals; and 2) explore interannual variations in cyclone 73 activity for the study area linked to large-scale atmospheric circulation.

74 We pursue objective 1 because despite the recognised role of cyclones as an important feature 75 of the BI climate, and of precipitation and flood frequency in particular (Allan et al., 2009; 76 Pattison and Lane, 2012; Wilby and Quinn, 2013), relatively little attention has been directed 77 toward their seasonal characteristics, or influence on surface climate. In constructing the 78 longest direct record of BI cyclonicity to-date, our study is well placed to make a contribution in this regard. Objective 2 is addressed because changes in cyclone activity over the region and their drivers are of the utmost societal concern. Our study allows emergent cyclone properties to be viewed in the context of a 142-year period, facilitating assessment of lowfrequency variations in cyclone activity and the role of wider-scale atmospheric processes in driving cyclone activity.

The following sections provide details of the data (Section 3) and methods (Section 4) used in our study, before proceeding to the results in Section 5. There we outline the role of cyclones within the regional hydroclimate (5.1) and interpret the temporal variability in cyclone activity, including coupling to larger-scale atmospheric processes (5.2). These results are then discussed in Section 6 and conclusions are drawn in Section 7.

\section{Data}

\subsection{The Twentieth Century Reanalysis V2}

91 The 20CR project is described in detail by Compo et al. (2011). Briefly, the product provides 92 a comprehensive tropospheric reanalysis spanning the period 1871-2012 at $2^{\circ} \times 2^{\circ}$ spatial 
British-Irish Isles cyclone climatology

93 resolution, based on a 56-member ensemble using only observations of surface air pressure, 94 sea surface temperatures, and sea ice extent. Uncertainty in the reanalysis is quantified by the 95 spread among ensemble members. Here 20CR data were extracted for each ensemble member at six-hourly resolution (1871-2012: provided by NOAA/OAR/ESRL PSD available at http://www.esrl.noaa.gov/psd/) for the $\mathrm{BI}$ domain $\left(50^{\circ} \mathrm{N}\right.$ to $60^{\circ} \mathrm{N}, 16^{\circ} \mathrm{W}$ to $\left.6^{\circ} \mathrm{E}\right)$ used by Matthews et al. (2014).

Whilst the accuracy of $20 \mathrm{CR}$ is described as equivalent to contemporary three-day numerical weather predictions, quality in the earlier part of the record has been questioned in assessments of storminess, particularly for data-sparse periods and regions (Wang et al., 2013; Krueger et al., 2014). In particular, variations in the number of observations assimilated into the 20CR through time challenges the identification of trends in storm activity (Section 4.2), as detected changes may be a spurious consequence of changing data quality (Wang et al., 2013). However, previous research suggests that the 20CR is most likely of good quality and homogeneous throughout the BI region (Wang et al., 2014; Matthews et al., 2014). Figure 1 shows that data quality over the BI and Western Europe is less uncertain and quality degrades relatively little earlier in the record, compared with the mid/high latitude Northern Hemisphere as a whole. Thus, our domain is amongst the most stable regions and, therefore, amenable to producing a robust, long-term cyclone climatology from the 20CR.

\subsection{Lamb Weather Types and Precipitation}

To corroborate our 20CR cyclone climatology we compared cyclone counts with the number of pure and hybrid cyclonic Lamb Weather types (LWTs) classified objectively by Jones et al. (2013) centred on the BI using the 20CR for the period 1871-1947, and the National Centers

115 for Environmental Prediction/National Centre for Atmospheric Research Reanalysis 116 (NCEP/NCAR: Kalnay et al., 1996) for the period 1948-present. The cyclonic LWTs are a 117 useful comparison for our counts because the former have a long legacy in regional 118 climatology (Lamb, 1972) and the Jones et al. (2013) version of the catalogue employed here 119 has already demonstrated wider utility in hydrological assessment for the BI back to the $19^{\text {th }}$ 120 Century (e.g. Wilby and Quinn, 2013). We refer to pure and hybrid cyclonic LWTs following 121 the terminology of Lamb (1972), whereby hybrids are those which are a mix of pure synoptic 122 (in this case cyclonic) and directional circulations (e.g. northwest). Objective rules for 123 determining the LWTs are based on geostrophic flow strength/direction and relative vorticity; 124 a description of this scheme can be found in Jones et al (1993, 2013). 
British-Irish Isles cyclone climatology

125 In exploring seasonal cyclone climatologies we assessed the correlation between cyclone 126 metrics and rainfall totals in the gridded CRU TS3.21 dataset (Harris et al., 2014) which 127 covers the period 1901-2012 at $0.5^{\circ} \times 0.5^{\circ}$ spatial resolution. We also use the long-running 128 England and Wales Precipitation (EWP) record (Alexander et al., 2001) to assess any 129 association between years of extreme cyclone activity and precipitation.

130 To determine links between large-scale atmospheric processes and interannual variability in 131 cyclonicity, we used three indices to describe atmospheric flow in the North Atlantic region: 132 the North Atlantic Oscillation Index (NAOI: Hurrel, 1995), Greenland Blocking Index (GBI: 133 Fang, 2004), and the Blocking Index of Tibaldi and Molteni (1990), extended to two 134 dimensions (Scherrer et al., 2006), and hereafter referred to as BITM. This index identifies 135 blocks by a meridional reversal of the normal poleward geopotential height gradient at the $136500 \mathrm{hPa}$ level. The GBI and BITM were thus calculated using the height field of the $500 \mathrm{hPa}$ 137 surface extracted from the $20 \mathrm{CR}$ at monthly and daily resolution, respectively. Two versions 138 of the NAOI were used: a principal component (PC) series, derived from the monthly mean 139 20CR sea-level pressure fields, and the station-based index (data provided by the Climate 140 Analysis Section, NCAR available at: https://climatedataguide.ucar.edu/climate-data/hurrell141 north-atlantic-oscillation-nao-index-station-based).

\section{Methods}

\subsection{Cyclone Identification and Metrics}

144

Following Matthews et al. (2014) cyclones were identified using an objective algorithm: an implementation of the Serreze et al. (2008) scheme for a regular latitude/longitude grid. The technique classifies cyclones based on the local Laplacian of sea-level pressure. As in Matthews et al. (2014) we apply a threshold criterion that a sea-level pressure gradient of at least $1 \mathrm{hPa} 250 \mathrm{~km}^{-1}$ must be present between a low centre and surrounding cells to qualify as a cyclone.

The algorithm was applied by scanning each six-hourly grid from the 56 ensemble members separately. When a cyclone is identified, the location (lat/lon) of the cyclone centre and local Laplacian (intensity: $L$ ) are stored. Three cyclone metrics for the BI domain were tallied at seasonal resolution: cyclone counts $\left(C_{i, j}\right)$, which are simply the number of cyclone centres observed in all grids during year $i$ and season $j$ (note that this measure is equivalent to the "cyclone centre count" as defined in Neu et al., 2013); mean cyclone intensity $\left(\bar{L}_{i, j}\right) \mathrm{z}$ calculated as the arithmetic mean of the local Laplacians for the $C_{i, j}$ cyclones; and the 
British-Irish Isles cyclone climatology

157 Cyclone Activity Index (CAI: Wang et al., 2006), given by $C A I_{i, j}=C_{i, j} \bar{L}_{i, j}$. The $C A I$ thus 158 weights total counts by mean cyclone intensity. Note that the Laplacian is equivalent to the 159 geostrophic relative vorticity around the cyclone centre and is, therefore, an indicator of low160 level convergence. We follow the terminology of Matthews et al. (2014) and refer to the CAI 161 as 'storminess' hereafter. Metrics were calculated for each of the 56 ensemble members then 162 averaged to produce an ensemble-mean series. Seasons were defined as successive three163 month blocks with winter as December (from previous calendar year) to February.

\subsection{Interannual variability in cyclonicity}

To assess interannual variability in BI cyclonicity we calculated trends in cyclone metrics over the 142-year (1871-2012) period and examined periods of enhanced storminess cyclone activity in detail. Trends were defined using the non-parametric Theil-Sen slope estimation method (Theil, 1950; Sen, 1968). This metric gives a robust estimate of linear trend in the presence of outliers by using the median slope from an ensemble of trends calculated between every pair of $x-y$ data coordinates. Trend significance (two-tailed) was assessed using the non-parametric Mann-Kendall test (Mann, 1945; Kendall, 1975). Although we report significance for all statistical tests at the $5 \%$ level, these values should be interpreted with caution. There is growing recognition that statistical significance is challenging to establish due to the difficulty of defining a valid null hypothesis in poorly understood physical systems (see Cohn and Lins, 2005), as well as dependency of trend significance on choice of start and end dates (e.g. Murphy et al., 2013).

We also recommend that trends should be viewed critically. Although reanalysis projects employ a physically-consistent and temporally-fixed framework for assimilating data, the spatial density of climate observations is not constant though time, which means that archives cannot be considered homogeneous (Chang and Fu, 2002; Smits et al., 2005; Hanna et al., 2008). This problem is apparent for reanalysis datasets in general, and can result in spurious variability and trends (Dee et al., 2014). Whilst attempts have been made to correct for inhomogeneities in the 20CR itself (Wang et al., 2013), these corrections are not without a degree of subjectivity, as statistically-identified change points used to correct data may reflect legitimate climatic variations. Faced with these complexities we, therefore, select the simplest and most transparent solution of reporting trends based on raw 20CR data and use the significance as a relative indicator of trend strength. The trend analysis is thus included for completeness and comparison with previous studies. Note that the 20CR has been used in the 
British-Irish Isles cyclone climatology

189 same unadjusted format for the relatively high-quality data of the BI region by Jones et al. 190 (2013), Donat et al. (2011) and Brönnimann et al., (2012), with the latter two studies also 191 conducting trend analyses on these unadjusted data.

192 Individual seasons and spells of enhanced cyclone activity were identified by ranking years 193 and decades according to each cyclone metric. Years characterised as extreme were used to 194 explore the role of wider-scale atmospheric processes in driving enhanced cyclone frequency 195 and intensity. This was achieved by compositing standardized $500 \mathrm{hPa}$ height anomalies for 196 those seasons in the top 5\% when ranked by the respective cyclone metric (cyclone frequency 197 or intensity). The $500 \mathrm{hPa}$ surface was chosen for analysis as this provides information about 198 atmospheric flow in the mid- and upper-troposphere, permitting insight into the dynamical 199 process generating and steering storms over the North Atlantic.

200 Linear associations between BI cyclone frequency and intensity with wider-scale circulation 201 were explored by calculating Pearson product-moment correlation coefficients between these 202 variables and the NAOI, GBI and BITM. The NAOI was calculated as the monthly time 203 series of the leading empirical orthogonal function of sea-level pressure over the region 20$20480^{\circ} \mathrm{N}, 40-90^{\circ} \mathrm{W}$ (e.g. Blessing et al., 2005; Hanna et al., 2014), whilst the GBI was computed 205 as the geopotential monthly height anomaly for the $500 \mathrm{hPa}$ surface over the region $60-80^{\circ} \mathrm{N}$, 206 20-80 W (Fang, 2004; Hanna et al., 2013). BITM was calculated for the Atlantic sector (34$20776^{\circ} \mathrm{N}, 84^{\circ} \mathrm{W}-44^{\circ} \mathrm{E}$ ) following the method outlined in Scherrer et al. (2006). Unless otherwise 208 stated, all correlations cited below are regarded significant when $p \leq 0.05$.

209 5. Results

\subsection{Cyclone metrics, Lamb Weather Types and rainfall}

Correlations between our (20CR) cyclone counts and total pure and hybrid cyclonic LWTs (Figure 2) are all statistically significant. Correlation strength is generally greater between 20CR and hybrid cyclonic weather types and in winter. 20CR total cyclone counts are higher (lower) than the number of pure (hybrid) cyclonic LWTs, consistent with the findings of Matthews et al. (2014) for their winter-only assessment. The overestimation compared to counts of pure cyclonic LWTs may be because we sample the pressure field more frequently (six-hourly here versus 24-hourly in the LWT analysis), meaning that short-lived lows are more likely to be detected. The fact that the number of hybrid cyclonic LWTs exceeds our cyclone counts could be due to the more stringent definition of a cyclone employed here, 
British-Irish Isles cyclone climatology

220 which includes an intensity threshold. This may also explain why correlation between LWT

221 counts and our cyclone metrics are weaker outside of winter. Mean cyclone intensity is lower

222 in warmer months and, in the presence of weaker lows, there is evidently a greater chance of

223 disagreement in the detection of a cyclone according to these classification schemes (see

224 below for details of the seasonal cycle in cyclone intensity).

225 Correlation surfaces for interannual seasonal rainfall variability and cyclone metrics are

226 shown in Figure 3. Correlations between our metrics and rainfall are significant not just for

227 the BI, but for large parts of northwest Europe. Maps of counts and storminess appear similar

228 because interannual variations in storminess are mainly driven by cyclone counts. This metric

229 has a higher standard deviation than intensity when expressed as a percentage of the mean $\left(C_{v}\right.$

230 of $18.7 \%$ versus $6.0 \%$ : see Table 1 and Section 5.3 ) and storminess is calculated with a

231 multiplicative formula (Section 4.1). For conciseness, we focus on the correlation for cyclone

232 counts.

233 In winter, an area of significant positive correlations with cyclone frequency extends over

234 much of northwest Europe, with the exception of western Scandinavia which registers

235 significant negative correlations. In summer, the area exhibiting significant correlations

236 between the cyclone metrics and precipitation contracts and the strength of the correlations

237 throughout northern Europe is also generally lower, particularly for western Scandinavia.

238 However, average correlation strength is greatest across the BI during summer and there is a

239 weak spatial gradient in correlation across the domain. This is unlike winter where there is a

240 noteworthy decrease in the strength of the correlation between cyclone count and

241 precipitation with increasing latitude, becoming non-significant for northwest Scotland. In

242 this region, cyclone intensity is significantly correlated with precipitation.

243 The seasonal regime of cyclone metrics is illustrated in Figure 4. Mean cyclone intensity

244 progresses from a maximum during winter to minimum in summer. The seasonal change in 245 counts is more complex. The probability of cyclone presence over the BI is greatest in late 246 summer (August), with secondary peaks in late spring (May) and late autumn (November).

247 Minimum cyclone frequency occurs in winter. Further insight into this aspect of cyclonicity

248 of the region is provided by Figure 5, where counts are aggregated into three-month seasons

249 for consecutive 30-year periods (except the abridged period 1991-2012). The summer peak in

250 cyclone frequency is evident again, but interestingly the seasonal maxima is absent from

251 1961-1990. According to Figure 4, the stormiest period for the BI generally occurs in late 
British-Irish Isles cyclone climatology

252 autumn, as the secondary peak in cyclone frequency combines with the symmetrical cycle in 253 intensity which ascends from the summer minima.

\subsection{Interannual variability in BI cyclonicity}

255

Annual and seasonal series of cyclone metrics are shown in Figure 6; coefficients of variation and linear trends are presented in Table 1. Cyclone counts exhibit greatest year-to-year variability. Seasonally, both cyclone frequency and intensity are most variable in winter, with the standard deviation exceeding $40 \%$ of the mean for the former. Regarding trends, counts in all seasons have decreased over the period analysed, but the decline is weak and nonstatistically significant. Stronger trends are observed for mean cyclone intensity which has increased in all seasons, with the strongest and weakest trends in winter and summer, respectively. The counteracting effects of decreasing cyclone counts with increased mean intensity, results in no net change in storminess throughout the period of study: trends for this metric are increasing for all seasons except spring, but all are very weak and statistically insignificant.

The top seven years (corresponding to $\sim 5 \%$ of the record) by cyclone frequency, intensity and storminess are shown in Table 2, while inter-decadal variation in cyclonicity is ranked and illustrated in Figure 7. The stormiest year was 1872 due to high cyclone frequency in winter and autumn. More recently, the years 2000 and 2009 feature as extreme and summer 2012 also registers as exceptional. This extreme seasonal storminess joins the winter of 2013/2014, which Matthews et al. (2014) determined as unprecedented since 1871/72 by updating the winter 20CR BI cyclone series to 2013/2014 using the NCEP reanalysis. The stormiest decade was the $1910 \mathrm{~s}$, mainly due to frequent cyclones in winter and spring. The second and third stormiest decades were the 1920s and 1980s respectively, with the 1920s peak driven by frequent cyclones in spring, summer and autumn, which were also intense in the latter two seasons. The storminess of the 1980 s is due to very high cyclone intensity: this decade experienced the most intense cyclones in every season except winter, where it ranked second according to this metric. The quietest decade for storminess was the 1970s on account of the relatively low number of cyclones in spring and summer. The decades of lowest cyclone intensity are mainly found in the earlier part of the record in all seasons, with the $1870 \mathrm{~s}, 1880 \mathrm{~s}$ and $1890 \mathrm{~s}$ ranked $14^{\text {th }}, 13^{\text {th }}$ and $12^{\text {th }}$, respectively. This is consistent with the strongly increasing trends found for this metric (Table 1).

\subsection{BI cyclonicity and atmospheric circulation}


British-Irish Isles cyclone climatology

284 To explore how the frequency and intensity of cyclones relate to larger-scale atmospheric circulation, we used the years listed in Table 2 to produce composite plots of anomalies at the $500 \mathrm{hPa}$ level (Figure 8). The most coherent anomalies are observed for winter when high cyclone frequency is associated with a low height anomaly over a broad region of the northeast Atlantic, approximately centred over the BI. The downstream anomaly is reminiscent of a Rossby wave train with alternating high/low height anomalies, whilst upstream there is a suggestion of higher geopotential heights in the vicinity of Greenland. A clear geopotential height anomaly signal also emerges in winter when cyclone intensity is considered. Seasons with more intense cyclones are characterised by a height field with positive (negative) anomalies in the low (high) latitudes of the North Atlantic. Outside of winter, coherence in the anomaly field for years of extreme cyclonicity is less evident for both cyclone counts and intensity. In all seasons more frequent cyclones act to lower geopotential heights in the vicinity of the BI.

297

To further investigate the link between cyclonicity and larger scale atmospheric circulation we also determined associations between cyclone metrics and indices of atmospheric circulation in the North Atlantic region. As the BITM is a two-dimensional index, we explore associations between blocking frequency at each grid point and cyclone frequency/intensity (Figure 9). For all seasons an increase in cyclone frequency for the BI is associated with a decrease in blocking over the region and an increase in blocking at higher latitudes over the Atlantic. In winter the area of significant positive correlations between high-latitude blocking and BI cyclone frequency is relatively extensive, with significant correlations found to the west and east of Greenland. In other seasons, positive correlations only persist to the east. In spring, summer, and autumn, cyclone intensity generally exhibits weaker correlations (than frequency) with blocking. During the winter months, cyclones over the BI tend to be more intense when blocking is increased (decreased) to the south (north) of the islands.

Correlations between the cyclone metrics and the NAOI and GBI are provided in Table 3. For comparison, and on the basis of Figure 9, we also report correlations between blocking frequency for the BI domain $\left(50-60^{\circ} \mathrm{N}, 16^{\circ} \mathrm{W}-6^{\circ} \mathrm{E}\right.$; hereafter 'BIBF' - BI Blocking Frequency) and cyclone frequency/intensity. BIBF is defined as the daily probability of at least one grid cell being blocked within the BI domain. The strongest correlations for cyclone counts are observed for BIBF, but significant correlations are similarly apparent between frequency and both the NAOI and GBI. These indices are also significantly correlated with average cyclone 316 intensity. The results indicate that periods of positive (negative) NAO (GBI) conditions are 
British-Irish Isles cyclone climatology

317 associated with fewer, but more intense cyclones over the BI. This relationship breaks down 318 somewhat in summer (no significant correlation with cyclone intensity) and autumn (no 319 significant correlation with cyclone frequency), but is otherwise persistent. This is 320 characteristic of the fact that, with the exception of the association between BIBF and counts, 321 correlations between cyclone metrics and circulation indices are generally strongest in the 322 winter.

\section{Discussion}

\subsection{BI cyclonicity and regional hydroclimate}

The 142-year record yields new insights into the cyclone climate of the BI. Strong and statistically significant correlations between seasonal precipitation and cyclone frequency confirm the regional hydroclimatic importance of cyclones. The stormiest periods have also been recognised as extreme in other hydroclimatic indicators: e.g. the top-ranking winter (1915) and autumn (2000) are the wettest in the long-running EWP series for the overlapping period (1871/72-2012), whilst the stormiest spring (1983) and summer (2012) also rank highly $\left(4^{\text {th }}\right.$ and $3^{\text {rd }}$, respectively). Extensive seasonal flooding has additionally been documented during periods recognized as extremely stormy: e.g. autumn 2000 (Marsh and Dale, 2002; Jones et al., 2006), and summer 2012 (Parry et al., 2012; Dong et al., 2013a). Moreover, the stormiest year (1872) is wettest in the EWP series and has been noted as a particularly flood-rich period (Jones et al., 2006; Wilby and Quinn, 2013). The most subdued decade in terms of storminess (the 1970s) was a period of exceptional drought in the BI (Jones et al., 2006; Marsh et al., 2007; Rodda and Marsh, 2011; Murphy et al., 2013). Correspondence with independent hydroclimatic indicators highlights the importance of cyclones for the regional hydroclimate, and simultaneously corroborates the 20CR cyclone reconstruction.

Correlation between precipitation and cyclone counts was highest during summer. This differs from Lavers et al. (2013), who found the relationship between mean sea-level pressure (MSLP) and precipitation across northwest Europe (including the BI) was weaker in summer than in winter. One explanation for this discrepancy is that the storm track is known to be more spatially restricted in summer than winter over the northeast Atlantic (Mesquita et al. 2008). Thus, where cyclone frequency is an important driver of precipitation totals, it is reasonable to expect that regions of significant correlations between rainfall totals and MSLP (which bare the imprint of depression passage) should be similarly constrained. The different 
British-Irish Isles cyclone climatology

349 period $(1957-2002)$ and spatial resolution $\left(2.5^{\circ} \times 2.5^{\circ}\right)$ of the reanalysis dataset used by 350 Lavers et al. (2013) could be another factor. In highlighting the importance of cyclones in 351 driving high precipitation amounts over the BI throughout the year, our results agree with 352 Murphy and Washington (2001), who, in all seasons, observed a cyclonic pattern in the 353 correlation field centred on the BI when assessing the association between mean sea-level 354 pressure and the leading Empirical Orthogonal Function of BI rainfall.

355 Correlations between summer precipitation and summer cyclone counts are more spatially356 consistent over BI relative to other seasons. During winter, correlations between cyclone 357 counts/storminess, and precipitation are insignificant for the northwest of our domain where 358 we observed stronger correlations between cyclone intensity and precipitation. Periods of 359 enhanced cyclone intensity for the BI have been associated with positive phases of the NAO 360 (Allan et al., 2009, and see Section 6.2). This correspondence is strongly hinted at in Figure 3 361 as the correlation between BI cyclone intensity and precipitation mirrors the association 362 between the NAOI and European winter precipitation (Wilby et al., 1997; Trigo et al., 2002), 363 reflecting the more northerly (southerly) position of the storm track during NAO positive 364 (negative) conditions. When cyclones take a more northerly route over the northeast Atlantic, 365 they will not be counted in our BI domain but may still enhance seasonal precipitation in the 366 northwest BI through the passage of trailing fronts. During positive NAO conditions, the 367 stronger westerly flow is also understood to increase orographic rainfall for the British 368 uplands (Burt and Holden, 2013). These mechanisms explain the lack of correlation between 369 cyclone counts and precipitation in the northwest in winter: precipitation can be enhanced in 370 the northwest BI by the passage of "local" cyclones (which will register in our counts) 371 through low-level convergence and frontal lifting, but also by "remote" cyclones north of our 372 domain, as both trailing fronts and enhanced orographic uplift associated with a more 373 northerly storm track are important rainfall generating mechanisms. We suggest that in winter 374 the latter are more important, due to the stronger westerly flow, but that in summer the former 375 emerges as dominant when the westerly flow weakens (cf. Wilby et al., 2002). This would 376 also account for the more spatially homogenous summer correlation field in Figure 3. 377 Regardless of the physical processes driving correlations, cyclone frequency has already been 378 linked to spatially-extensive flooding episodes (Wilby and Quinn, 2013) due to high rainfall 379 amounts across the BI associated with cyclone passage (Burt et al., 2014). We emphasise that 380 these conclusions are perhaps most appropriate for summer based on the evidence presented 381 here. 
British-Irish Isles cyclone climatology

382

383

384

385

386

387

388

389

390

391

392

393

394

395

396

397

398

399

400

401

402

403

404

405

406

407

408

409

410

411

412

\subsection{Atmospheric circulation and temporal variability in BI cyclonicity}

Days with cyclonic circulation over the BI are most frequent in summer. This finding is consistent with Mesquita et al. (2008) who showed that the northeast North Atlantic is among the few regions in the Northern Hemisphere to experience a summer cyclone maximum. The assessment of cyclonicity (Section 5.4) provides some insight to physical processes driving the seasonal cycle in cyclone frequency. Cyclone counts were found to correlate most strongly with the BIBF, such that increased regional blocking translates into fewer cyclonic circulation days. This fits with the summer-only investigation of Dong et al. (2013b) and agrees with the negative correlation between cyclonic and anticyclonic LWTs noted by Burt et al. (2014). Figure 10 (left) demonstrates that this relationship generally holds when the seasonal climatological cycle is assessed: the blocking minimum in summer, characteristic of conditions across the north-eastern margin of Europe (Figure 10 - right), coincides with the summer cyclone maxima. The relationship between interannual blocking and cyclone frequency is further highlighted by anomalous conditions during the 1961-1990 climate normal period (cf. Section 6.1 and Figure 5), during which the summer cyclone maximum was not observed. This was also a 30 -year period characterised by frequent summer blocking (Table 4). It is interesting to note that a 30-year period (1961-1990) widely used to define climate normals was actually highly unusual from the perspective of summer atmospheric circulation for the BI.

To assess the role of larger-scale atmospheric processes modulating BI cyclonicity climate, we correlated cyclone metrics with climate indices. The GBI and NAOI exhibited correlation coefficients that were opposite in sign, which is unsurprising given the association between Greenland blocking and the NAO (Woolings et al., 2008). As correlations were stronger for the NAOI, we focus on this index here. Interannual variability in cyclone frequency was generally found to be negatively correlated with the NAOI in most seasons, the signal being strongest (highest $r$ values) using the PC-based NAOI, and in winter. The sign of relationship is consistent with analyses using the cyclonic LWT (e.g. Wilby et al., 1997; Burt et al., 2014). Negative correlation may reflect either slower-moving cyclonic systems during NAO negative years (subdued westerly circulation), or the passage of more cyclonic weather systems, as both processes could contribute to a higher number of cyclone days for our domain. 
British-Irish Isles cyclone climatology

413 Cyclone intensity was positively correlated with the NAOI in most seasons, with strongest 414 associations in winter, which concurs with Allan et al. (2009) and Wang et al. $(2009,2011)$.

415 The relationship between the NAO and cold-season cyclone intensity is also consistent with 416 the intense winter storminess identified during the 1990s (exceptionally positive NAO - see 417 Hanna et al., 2014)) in this study (Section 5.4) and in previous investigations (Jones et al., 418 1999; Allan et al., 2009; Wang et al., 2009, 2011; Cornes and Jones, 2011; Donat et al., 2011). 419 Whilst the NAOI exhibits statistically significant correlations with our cyclone metrics, we 420 note that even during winter when these associations are strongest, the NAO only accounts 421 for $\sim 16$ and $31 \%$ of the variance in cyclone frequency and intensity, respectively. Thus, the 422 utility of the NAO for interpreting BI cyclonicity is perhaps limited (cf. Burningham and 423 French, 2013).

424 Our results suggest an increase in cyclone intensity for all seasons over the BI that is 425 strongest in winter. Detailed comparison with other research is confounded by differences in 426 the choice of metrics, domains and sampling resolutions. However, increased BI cyclone 427 intensity is broadly supported by investigations of trends in extreme wind speeds using the 428 20CR (Brönnimann et al., 2012; Donat et al., 2012) and by Wang et al. (2013) who found 429 increasing mean Laplacian from the 20CR for the high-latitude North Atlantic (in which our 430 domain is mostly situated). These results stand in contrast with studies using in-situ pressure 431 observations to determine changes in BI cyclone intensity (e.g. Hanna et al., 2008; Wang et 432 al., 2009, 2011). Although such contradictions regarding the 20CR has been raised before 433 (Krueger et al., 2014; Wang et al., 2014) the cause remains unclear. Improved understanding 434 of this disagreement is needed as enhanced cold-season cyclone intensity has been projected 435 for the BI region (Collins et al., 2013; Zappa et al. 2013; Feser et al., 2014). Robust long-term 436 cyclone climatologies are required if emerging trends are to be differentiated from natural 437 variability.

438 Cyclone frequency and storminess were more closely related to interannual variation in BI 439 precipitation. Recent years have seen three of the stormiest seasons on record, with autumn 440 (2000) and summer (2012) joining the winter of 2013/2014 (see Matthews et al. (2014)) as 441 the most exceptional seasons since the beginning of 20CR. Despite this clustering, we 442 detected no evidence for an upward trend in storminess, reflecting the signal (or lack of) in 443 cyclone frequency compared to the noise of interannual variability. However, pronounced, 444 low-frequency variability in these metrics is evident, which underscores the utility of the 445 long-term cyclone climatology presented here in contextualising recent extremes. For 
British-Irish Isles cyclone climatology

446 example, the highly-subdued storminess observed during the 1961-1990 climate normal 447 period has perhaps made the return to more typical conditions in recent years seem unusual.

448 Trends with start dates during this quiescent period are likely to be misleading: calculating 449 the Mann Kendall test statistic on the period 1979-2012 (the period of satellite observation 450 that signals the start date of the ERA-Interim Reanalysis dataset: Dee et al. (2011)), yields 451 upward trends in summer cyclone frequency and storminess with $p$-values of 0.017 and 0.044 , 452 respectively. Thus, despite the higher quality of more recent gridded data products for 453 objective assessment of atmospheric circulation, there remains a need for the longer-term 454 perspective afforded by products such as the 20CR is clear.

\section{Conclusions}

456 We have constructed a 142-year cyclone climatology for the BI using the 20CR. This product 457 both confirms and clarifies the importance of cyclones to the hydroclimate of this region. 458 Seasonal precipitation totals were found to be strongly correlated with cyclone frequency 459 across large parts of the BI, but this is most apparent during the summer, when these weather 460 types are more frequent. We therefore conclude that any changes in the frequency of "local" 461 cyclones for the region would be particularly important for seasonal precipitation totals 462 during summer. In this context, we detected no trend in cyclone frequency or storminess in 463 any season, but did establish that the 1961-1990 climate normal was extraordinary for the 464 rarity of summer cyclones, which is consistent with the severe droughts reported for the same 465 period. Such low-frequency variability in cyclone frequency was found to be strongly 466 associated with atmospheric blocking - a control which also emerged when the seasonal 467 cycle in this metric was assessed. Thus, we emphasise that to better understand the processes 468 driving variability in the frequency of cyclones for the BI, it is necessary to investigate 469 mechanisms that modulate atmospheric blocking in the Euro-Atlantic sector.

470 Cyclone intensity was observed to be significantly correlated (positive) with the NAOI, 471 particularly in winter, which is generally in agreement with the literature. However, our 472 detection of a strong upward trend in cyclone intensity highlights a discrepancy between 473 long-term reanalysis reconstructions and assessments of cyclone intensity based on station 474 data. Given expectations of enhanced cyclone activity for the BI in a warmer climate, we 475 emphasise that resolving this matter should be a high priority for future research.

\section{References}


British-Irish Isles cyclone climatology

477 Alexander LV and Jones PD. 2001. Updated precipitation series for the UK and discussion of 478 recent extremes. Atmos. Sci. Let. 1: 142-150.

479 Alexandersson H. Schmith T, Iden K. and Tuomenvirta H. 1998. Long-term variations of the 480 storm climate over NW Europe. The Global Atmosphere and Ocean System 6: 97-120.

481 Alexandersson H, Tuomenvirta H, Schmith T and Iden K. 2000. Trends of storms in NW 482 Europe derived from an updated pressure data set. Clim. Res. 14: 71-73.

483 Allan R, Tett S and Alexander L. 2009. Fluctuations in autumn-winter severe storms over the 484 British Isles: 1920 to present. Int. J. Climatol. 29: 357-371.

485 Blackburn M, Methven J and Roberts N. 2008. Large-scale context for the UK floods in 486 summer 2007. Weather 63: 280-288.

487 Blessing S, Fraedrich K, Junge M, Kunz T, Lunkeit F. 2005. Daily North-Atlantic Oscillation 488 (NAO) index: Statistics and its stratospheric polar vortex dependence. Meteorol. Z. 14: $763-$ 489769.

490 Brönnimann S, Martius O, Von Waldow H, Welker C, Luterbacher J, Compo GP, 491 Sardeshmukh PD, and Usbeck T. 2012. Extreme winds at northern mid-latitudes since 492 1871. Meteorol. Z. 21: 13-27.

493 Burningham $\mathrm{H}$ and French J. 2013. Is the NAO winter index a reliable proxy for wind 494 climate and storminess in northwest Europe?. Int. J. Climatol., 33: 2036-2049.

495 Burt TP and Howden NJK. 2013. North Atlantic Oscillation amplifies orographic 496 precipitation and river flow in upland Britain. Water Resour. Res. 49: 3504-3515.

497 Burt TP, Jones PD and Howden NJK. 2014. An analysis of rainfall across the British Isles in 498 the 1870s. Int. J. Climatol. DOI: 10.1002/joc.4184

499 Chang EKM and Fu Y. 2002. Interdecadal variations in Northern Hemisphere winter storm 500 track intensity. J. Climate 15: 642-658.

501 Cohn TA and Lins HF. 2005. Nature's style: Naturally trendy. Geophys. Res. Lett 32: L23402. 
British-Irish Isles cyclone climatology

502 Collins M, Knutti R Arblaster J Dufresne J-L, Fichefet T, Friedlingstein P, Gao X, 503 Gutowski WJ, Johns T, Krinner G, Shongwe M, Tebaldi C, Weaver AJ and Wehner M. 504 2013: Long-term Climate Change: Projections, Commitments and Irreversibility. In: Climate 505 Change 2013: The Physical Science Basis. Contribution of Working Group I to the Fifth 506 Assessment Report of the Intergovernmental Panel on Climate Change [Stocker TF, Qin D, 507 Plattner G-K, Tignor M, Allen SK, Boschung J, Nauels A, Xia Y, Bex V and Midgley PM 508 (eds.)]. Cambridge University Press, Cambridge, United Kingdom and New York, NY, USA.

509 Compo G P, Whitaker JS, Sardeshmukh P D, Matsui N, Allan RJ. Yin X, Gleason BE, Vose 510 RS, Rutledge G, Bessemoulin P, Brönnimann S. Brunet M, Crouthamel RI, Grant AN, 511 Groisman PY, Jones PD, Kruk MC, Kruger AC, Marshall GJ, Maugeri M, Mok HY, Nordli $512 \varnothing$, Ross TF, Trigo RM, Wang XL, Woodruff SD and Worley SJ. 2011. The Twentieth 513 Century Reanalysis Project. Q.J.R. Meteorol. Soc. 137: 1-28.

514 Cornes RC and Jones PD. 2011. An examination of storm activity in the northeast Atlantic 515 region over the 1851-2003 period using the EMULATE gridded MSLP data series. $J$. 516 Geophys. Res. 116: D16110.

517 Cornes RC. 2014. Historic storms of the northeast Atlantic since circa 1700: a brief review of 518 recent research. Weather 69: 121-125.

519 Dee DP, Uppala SM, Simmons AJ, Berrisford P, Poli P, Kobayashi S, Andrae U, Balmaseda 520 MA, Balsamo G, Bauer P, Bechtold P, Beljaars ACM, Van de Berg L, Bidlot J, Bormann N, 521 Delsol C, Dragani R, Fuentes M, Geer AJ, Haimberger L, Healy SB, Hersbach H, Hólm EV, 522 Isaksen L, Kållberg P, Köhler M, Matricardi M, Mcnally AP, Monge-sanz BM, Morcrette J, 523 Park B, Peubey C, de Rosnay P, Tavolato C, Thépaut J and Vitart F. 2011. The ERA-Interim 524 reanalysis: configuration and performance of the data assimilation system. Q.J.R. Meteorol. 525 Soc 137: 553-597.

526 Dee D, Fasullo J, Shea D, Walsh John and National Center for Atmospheric Research Staff 527 (Eds). The Climate Data Guide: Atmospheric Reanalysis: Overview \& Comparison 528 Tables. Retrieved from https://climatedataguide.ucar.edu/climate-data/atmospheric529 reanalysis-overview-comparison-tables. Last modified 05 Nov 2014. 
British-Irish Isles cyclone climatology

530 Donat MG, Renggli D, Wild S, Alexander LV, Leckebusch GC, Ulbrich U. 2011. Reanalysis

531 suggests long-term upward trends in European storminess since 1871. Geophys. Res. Lett. 38:

532 L14703.

533 Dong B, Sutton R and Woolings T. 2013a. The extreme European Summer 2012 [in 534 "Explaining Extreme Events of 2012 from a Climate Perspective]. Bull. Amer. Meteor. Soc 9: 535 s28-s32.

536 Dong B, Sutton RT, Woollings T and Hodges K. 2013b. Variability of the North Atlantic 537 summer storm track: mechanisms and impacts on European climate. Environ. Res. Lett. 8: 538034037.

539 Esteves LS, Williams JJ and Brown JM. 2011. Looking for evidence of climate change 540 impacts in the eastern Irish Sea. Nat. Hazard. Earth Sys. 11: 1641-1656.

541 Fang ZF. 2004. Statistical relationship between the northern hemisphere sea ice and

542 atmospheric circulation during wintertime. In Observation, Theory and Modeling of

543 Atmospheric Variability. World Scientific Series on Meteorology of East Asia, Zhu X (ed).

544 World Scientific Publishing Company: Singapore; 131-141

545 Feser F, Barcikowska M, Krueger O, Schenk F, Weisse R and Xia L. 2014. Storminess over 546 the North Atlantic and northwestern Europe-A review. Q. J. Roy. Meteor. Soc. DOI: $547 \quad 10.1002 /$ qj. 2364

548 Hanna E, Cappelen J, Allan R, Jónsson T, Le Blancq F, Lillington T and Hickey K. 2008. 549 New insights into North European and North Atlantic surface pressure variability, storminess, 550 and related climatic change since 1830. Int. J. Climatol. 21: 6739-6766.

551 Hanna E, Jones JM, Cappelen J, Mernild SH, Wood L, Steffen K and Huybrechts P. 2013. 552 The influence of North Atlantic atmospheric and oceanic forcing effects on 1900-2010 553 Greenland summer climate and ice melt/runoff. Int. J. Climatol. 33: 862-880.

554 Hanna E, Cropper TE, Jones PD, Scaife AA and Allan R. 2014, Recent seasonal asymmetric 555 changes in the NAO (a marked summer decline and increased winter variability) and 556 associated changes in the $\mathrm{AO}$ and Greenland Blocking Index. Int. J. Climatol. DOI: $557 \quad 10.1002 /$ joc. 4157 
British-Irish Isles cyclone climatology

558 Harris I, Jones PD, Osborn TJ and Lister DH. 2014. Updated high-resolution grids of

559 monthly climatic observations - the CRU TS3.10 Dataset. Int. J. Climatol. 34: 623-642.

560 Hickey KR. 2003. The Storminess Record from Armagh Observatory 1796-1999. Weather 58: $56128-35$.

562 Hickey KR. 2011. The hourly gale record from Valentia Observatory, SW Ireland 1874-2008 563 and some observations on extreme wave heights in the NE Atlantic, Climatic Change 106: $564 \quad 483-506$.

565 Hurrell J W. 1995. Decadal trends in the North Atlantic Oscillation: regional temperatures 566 and precipitation. Science 269: 676-679.

567 Jones, P. D., Hulme, M., \& Briffa, K. R. 1993. A comparison of Lamb circulation types with 568 an objective classification scheme. Int. J. Climatol. 13: 655-663.

569 Jones PD, Horton EB, Folland CK, Hulme M, Parker DE and Basnett TA. 1999. The use of 570 indices to identify changes in climatic extremes. Climatic Change 42: 131-149.

571 Jones PD, Lister DH, Wilby RL and Kostopoulou E. 2006. Extended river flow 572 reconstructions for England and Wales, 1865-2002. Int. J. Climatol, 26: 219-231.

573 Jones PD, Harpham C and Briffa KR. 2013. Lamb weather types derived from reanalysis 574 products. Int. J. Climatol, 33: 1129-1139.

575 Kalnay E, Kanamitsu M, Kistler R, Collins W, Deaven D, Gandin L, Iredell M, Saha S, 576 White G, Woollen J, Zhu Y, Leetmaa A, Reynolds R, Chelliah M, Ebisuzaki W, Higgins 577 W, Janowiak J, Mo KC, Ropelewski C, Wang J, Jenne R and Joseph D. 1996: The 578 NCEP/NCAR 40-year reanalysis project. Bull. Amer. Meteor. Soc. 77: 437-471.

579 Kendall MG. 1975. Rank correlation methods. Charles Griffin: London

580 Krueger O, Feser F, Bärring L, Kaas E, Schmith T, Tuomenvirta H and von Storch H. 2014. 581 Comment on Trends and low frequency variability of extra-tropical cyclone activity in the 582 ensemble of twentieth century reanalysis by Xiaolan L. Wang, Y. Feng, GP Compo, VR 583 Swail, FW Zwiers, RJ Allan, and PD Sardeshmukh, Climate Dynamics, 2012. Clim. 584 Dynam. 42:1127-1128. 
British-Irish Isles cyclone climatology

585 Lavers D, Prudhomme C and Hannah DM. 2013. European precipitation connections with 586 large-scale mean sea-level pressure (MSLP) fields. Hydrolog. Sci. J 58: 310-327.

587 Lamb HH. 1972. British Isles weather types and a register of daily sequence of circulation 588 patterns, 1861-1971: Geophysical Memoir 116 HMSO, London.

589 Mann HB. 1945. Nonparametric tests against trend. Econometrica 13: 245-259.

590 Marsh TJ and Dale M. 2002. The UK Floods of 2000-2001: A Hydrometeorological 591 Appraisal. Water Environ. J. 16: 180-188.

592 Marsh T, Cole G and Wilby RL. 2007. Major droughts in England and Wales, 1800-2006. 593 Weather, 62: 87-93.

594 Matthews T, Murphy C, Wilby RL and Harrigan S. 2014. Stormiest winter on record for 595 Ireland and UK. Nature Clim. Change 4: 738-740.

596 Matulla C, Schöner W, Alexandersson H, Von Storch H and Wang XL. 2008. European 597 storminess: late nineteenth century to present. Clim. Dynam. 31: 125-130.

598 Mesquita MDS, Gunnar Kvamstø N, Sorteberg A and Atkinson DE. 2008. Climatological 599 properties of summertime extra-tropical storm tracks in the Northern Hemisphere. Tellus A, 600 60: $557-569$.

601 Murphy C, Harrigan S, Hall J and Wilby RL. 2013. Climate-driven trends in mean and high 602 flows from a network of reference stations in Ireland. Hydrolog. Sci. J. 58: 755-772.

603 Murphy SJ and Washington R. 2001. United Kingdom and Ireland precipitation variability 604 and the North Atlantic sea-level pressure field. Int. J. Climatol. 21: 939-959.

605 Neu U, Akperov MG, Bellenbaum N, Benestad R, Blender R, Caballero R, Cocozza A, Dacre 606 HF, Feng Y, Fraedrich K, Grieger J, Gulev S, Hanley J, Hewson T, Inatsu M, Keay K, Kew 607 SF, Kindem I, Leckebusch GC, Liberato MLR, Lionello P, Mokhov II, Pinto JG, Raible CC, 608 Reale M, Rudeva I, Schuster M, Simmonds I, Sinclair M, Sprenger M, Tilinina ND, Trigo IF, 609 Ulbrich S, Ulbrich U, Wang XL, and Wernli H. 2013. Imilast: a community effort to 610 intercompare extratropical cyclone detection and tracking algorithms. Bull. Amer. Meteor. 611 Soc. 94: 529-547. 
British-Irish Isles cyclone climatology

612 Parry S, Marsh T and Kendon M. 2013. 2012: from drought to floods in England and Wales. 613 Weather 68: 268-274.

614 Pattison I and Lane SN. 2012. The relationship between Lamb weather types and long-term 615 changes in flood frequency, River Eden, UK. Int. J. Climatol. 32: 1971-1989.

616 Raible CC, Della-Marta PM, Schwierz C, Wernli H and Blender R. 2008. Northern 617 Hemisphere extratropical cyclones: A comparison of detection and tracking methods and 618 different reanalyses. Mon. Weather Rev. 136: 880-897.

619 Rodda JC and Marsh TJ. 2011. The 1975-76 Drought - a contemporary and retrospective 620 review. National Hydrological Monitoring Programme series. NERC/Centre for Ecology and 621 Hydrology: Wallingford, UK.

622 Scherrer SC, Croci-Maspoli M, Schwierz C and Appenzeller C. 2006. Two-dimensional 623 indices of atmospheric blocking and their statistical relationship with winter climate patterns 624 in the Euro-Atlantic region. Int. J. Climatol. 26: 233-249.

625 Sen P K. 1968. Estimates of the regression coefficient based on Kendall's tau. J. Am. Stat. 626 Assoc. 63: 1379-1389

627 Serreze MC and Barrett AP. 2008. The summer cyclone maximum over the central Arctic 628 Ocean. J. Climatol. 21: 1048-1065.

629 Simmonds I and Keay K. 2000. Mean Southern Hemisphere extratropical cyclone behavior in 630 the 40-year NCEP-NCAR reanalysis. J. Climatol. 13: 873-885.

631 Smits A, Klein Tank AMG and Können GP. 2005. Trends in storminess over the Netherlands, 632 1962-2002. Int. J. Climatol. 25: 1331-1344.

633 Sweeney J. 2000. A three-century storm climatology for Dublin 1715-2000. Irish 634 Geography 33: 1-14.

635 Theil H. 1950. A Rank-invariant Method of Linear and Polynomial Regression Analysis I. 636 Nederlands Akad. Wetensch. Proc. 53: 386-392. 
British-Irish Isles cyclone climatology

637 Tibaldi S and Molteni F. 1990: On the operational predictability of blocking. 638 Tellus 42A:343-365.

639 Trigo RM, Osborn TJ and Corte-Real JM. 2002. The North Atlantic Oscillation influence on 640 Europe: climate impacts and associated physical mechanisms. Clim. Res. 20: 9-17.

641 Vilibić I and Šepić J. 2010. Long-term variability and trends of sea-level storminess and 642 extremes in European Seas. Global and Planet. Change 71: 1-12.

643 Wang XL, Swail VR and Zwiers FW. 2006. Climatology and changes of extratropical 644 cyclone activity: Comparison of ERA-40 with NCEP-NCAR reanalysis for 1958-2001. $J$ 645 Climatol 19: 3145-3166.

646 Wang XL, Zwiers FW, Swail VR and Feng Y. 2009. Trends and variability of storminess in 647 the Northeast Atlantic region, 1874-2007. Clim. Dynam. 33: 1179-1195.

648 Wang XL, Wan H, Zwiers FW, Swail VR, Compo GP, Allan, Vose RS, Jourdain S and Yin 649 X. 2011. Trends and low-frequency variability of storminess over western Europe, 1878650 2007. Clim. Dynam. 37: 2355-2371.

651 Wang XL, Feng Y, Compo GP, Swail VR, Zwiers FW, Allan RJ and Sardeshmukh PD. 2013. 652 Trends and low frequency variability of extra-tropical cyclone activity in the ensemble of 653 twentieth century reanalysis. Clim. Dynam. 40: 2775-2800.

654 Wang XL. Feng Y, Compo GP, Zwiers FW, Allan RJ, Swail VR and Sardeshmukh PD. 2014. 655 Is the storminess in the Twentieth Century Reanalysis really inconsistent with observations? 656 A reply to the comment by Krueger et al. (2013b). Clim. Dynam 42:1113-1125.

657 Wilby RL, O'Hare G. and Barnsley N. 1997. The North Atlantic Oscillation and British Isles 658 climate variability, 1865-1996. Weather 52: 266-276.

659 Wilby RL, Conway D and Jones PD. 2002. Prospects for downscaling seasonal precipitation 660 variability using conditioned weather generator parameters. Hydrol. Process. 16: 1215-1234.

661 Wilby RL and Quinn NW. 2013. Reconstructing multi-decadal variations in fluvial flood risk 662 using atmospheric circulation patterns. J. Hydrol. 487: 109-121. 
British-Irish Isles cyclone climatology

663 Woodworth PL and Blackman DL. 2002. Changes in extreme high waters at Liverpool since 664 1768. Int. J. Climatol. 22: 697-714.

665 Woollings T, Hoskins B, Blackburn M and Berrisford P. 2008: A new Rossby wave-breaking 666 interpretation of the North Atlantic Oscillation. J. Atmos. Sci. 65: 609-626.

667 Woollings T. 2010. Dynamical influences on European climate: an uncertain future. Phios.T 668 Roy. Soc. A 368: 3733-3756.

669 Woollings T, Gregory J M, Pinto JG, Reyers M and Brayshaw DJ. 2012. Response of the 670 North Atlantic storm track to climate change shaped by ocean-atmosphere coupling. Nat. 671 Geosci.5: 313-317.

672 Zappa G, Shaffrey LC, Hodges KI, Sansom PG and Stephenson DB. 2013: A Multimodel 673 Assessment of Future Projections of North Atlantic and European Extratropical Cyclones in 674 the CMIP5 Climate Models. J. Climate 26: 5846-5862, doi:10.1175/JCLI-D-12-00573.1. 
British-Irish Isles cyclone climatology

675 Tables

676 Table 1. Changes in cyclone metrics time series. Trends $(\beta)$ are given as change per decade in $\%$ of the mean over the whole 677 period. Trend significance (in brackets as a percentage) for the corresponding Mann-Kendall statistic (not shown).

678 Coefficients of variation $\left(C_{v}\right.$ : mean/standard deviation) are expressed as a percentage.

\begin{tabular}{lcccccc}
\hline & \multicolumn{2}{c}{ Count $(\boldsymbol{C})$} & \multicolumn{2}{c}{ Intensity $(\overline{\boldsymbol{L}})$} & \multicolumn{2}{c}{ Storminess $(\boldsymbol{C A I})$} \\
\cline { 2 - 7 } DJF & $\beta$ & $C_{v}$ & $\beta$ & $C_{v}$ & $\beta$ & $C_{v}$ \\
MAM & $-0.25(26.8)$ & 41.7 & $1.23(100.0)$ & 13.1 & $0.67(55.4)$ & 40.8 \\
JJA & $-0.86(74.7)$ & 33.2 & $0.67(99.4)$ & 10.5 & $-0.19(22.8)$ & 36.5 \\
SON & $-0.41(42.4)$ & 33.1 & $0.42(92.6)$ & 10.3 & $0.07(18.4)$ & 36.5 \\
Full year & $-0.36(38.0)$ & 36.6 & $0.83(99.9)$ & 11.1 & $0.35(34.0)$ & 38.2 \\
\hline
\end{tabular}

679

680 Table 2. Top seven ranked years (i.e. $5 \%$ of the dataset) for each cyclone metric by season. Note that Matthews et al. 681 (2014) found that winter of 2013/14 was the stormiest since 1871/72, based on NCEP reanalysis for years outside the $6821871 / 72-2012$ period of $20 \mathrm{CR}$.

\begin{tabular}{lccccccc}
\hline Rank & $\mathbf{1}$ & $\mathbf{2}$ & $\mathbf{3}$ & $\mathbf{4}$ & $\mathbf{5}$ & $\mathbf{6}$ & $\mathbf{7}$ \\
\hline DJF & 1915 & 1936 & 1960 & 1919 & 1951 & 1872 & 1977 \\
MAM & 1983 & 1981 & 1920 & 1909 & 1979 & 1888 & 1882 \\
JJA & 1927 & 1879 & 2012 & 1888 & 1912 & 1917 & 1882 \\
SON & 2000 & 1872 & 1935 & 1976 & 1960 & 1896 & 1974 \\
Full year & 1872 & 1927 & 1882 & 1916 & 1951 & 2000 & 1930 \\
& & & & Intensity & & 1907 & \\
DJF & 2012 & 1989 & 1990 & 1995 & 1993 & 1952 & 2000 \\
MAM & 1943 & 1982 & 2011 & 2007 & 2002 & 1963 & 1919 \\
JJA & 1986 & 1923 & 1948 & 1949 & 1956 & 1959 & 1962 \\
SON & 1986 & 1996 & 1991 & 1989 & 1954 & 1950 & 1945 \\
Full year & 1989 & 1986 & 1974 & 1984 & 1959 & 1990 & 2002 \\
& & & & Storminess & & & 1906 \\
DJF & 1915 & 1984 & 1936 & 1960 & 1910 & 1919 & 1900 \\
MAM & 1983 & 1981 & 1920 & 1908 & 1919 & 1922 & 1909 \\
JJA & 2012 & 1879 & 1927 & 1888 & 1986 & 1917 & 1956 \\
SON & 2000 & 1935 & 1872 & 1976 & 1916 & 1974 & 1896 \\
Full year & 1872 & 1927 & 1916 & 1930 & 1951 & 2000 & 2009 \\
\hline
\end{tabular}


1

2

3

4

5

6

7

8

9

10

11

12

13

14

15

16

17

18

19

20

21

22

23

24

25

26

27

28

29

30

31

32

33

34

35

36

37

38

39

40

41

42

43

44

45

46

47

48

49

50

51

52

53

54

55

56

57

58

59

60

British-Irish Isles cyclone climatology

684

685

686

687

688

689

690

\begin{tabular}{ccc}
\hline Period & Relative Cyclone Frequency (\%) & Relative Blocking Frequency (\%) \\
\hline $\mathbf{1 8 7 1 - 1 9 0 0}$ & 101.8 & 86.6 \\
$\mathbf{1 9 0 1 - 1 9 3 0}$ & 105.5 & 99.8 \\
$\mathbf{1 9 3 1 - 1 9 6 0}$ & 106.7 & 100.6 \\
$\mathbf{1 9 6 1 - 1 9 9 0}$ & 80.9 & 123.0 \\
$\mathbf{1 9 9 1 - 2 0 1 2}$ & 105.1 & 90.1 \\
\hline
\end{tabular}

Table 3. Correlation between BI cyclone metrics and atmospheric circulation indices. BIBF denotes the blocking frequency in the $\mathrm{BI}$ domain $\left(50-60^{\circ} \mathrm{N}, 16^{\circ} \mathrm{W}-6^{\circ} \mathrm{E}\right) ; 20 \mathrm{CR} \mathrm{PC}$ and station-based NAO indices are subscripted with ${ }_{\mathrm{pc}}$ and $\mathrm{station}_{\text {, }}$ respectively. Correlations in bold are significantly different from zero at $p<0.05$, according to a two-tailed $t$-test.

\begin{tabular}{|c|c|c|c|c|c|}
\hline Season & Cyclone metric & $\mathbf{N A O}_{p c}$ & NAO $_{\text {station }}$ & GBI & BIBF \\
\hline \multirow{2}{*}{$\stackrel{\underline{Z}}{\overrightarrow{0}}$} & Counts & $\begin{array}{l}-0.40 \\
\end{array}$ & $\begin{array}{l}-0.20 \\
\end{array}$ & 0.33 & -0.53 \\
\hline & Intensity & 0.56 & 0.48 & -0.48 & 0.05 \\
\hline \multirow{2}{*}{$\sum$} & Counts & -0.27 & -0.11 & 0.25 & -0.65 \\
\hline & Intensity & 0.26 & 0.19 & -0.26 & 0.05 \\
\hline \multirow{2}{*}{$\mathbb{J}$} & Counts & $\begin{array}{l}-0.33 \\
\end{array}$ & -0.09 & 0.21 & -0.65 \\
\hline & Intensity & 0.01 & 0.00 & -0.08 & 0.02 \\
\hline \multirow{2}{*}{ zo } & Counts & 0.01 & 0.12 & 0.13 & -0.68 \\
\hline & Intensity & 0.29 & 0.23 & -0.23 & -0.18 \\
\hline
\end{tabular}

Table 4. Relative cyclone and blocking frequency for the BI domain in summer for 30-year normal periods (except 19912012). Here blocking frequency is calculated according to the definition of the BIBF with percentages derived relative to the long-term (1871-2012) summer mean.

691

692

693

694 
British-Irish Isles cyclone climatology

\section{Figure captions}

696 Figure 1. Panels a and $\mathbf{b}$ indicate the decadal mean standard deviation of daily-mean sea-level pressure amongst the 56

$69720 \mathrm{CR}$ ensemble members for the respective decades. To produce these fields, the standard deviation of the daily mean sea-

698 level-pressure was calculated across the 56 ensemble members at each grid cell. Time averages for these fields were then

699 calculated for each grid cell and respective decade. Panel $\mathbf{c}$ shows the data in the middle panel as a fraction of that plotted in

700 a. The larger the fraction, the less uncertainty has changed with time implying greater homogeneity in those regions.

701 Figure 2. Relationship between 20CR cyclone counts and total pure (left) and hybrid (right) cyclonic LWTs. Seasonal correlation coefficients (multiplied by 100) between series are also shown. Solid black lines denote the 1:1 relationship.

703 'Cyclone days' is defined as the number of cyclones identified in the six-hourly grids, divided by 4 (to be consistent with the

704 once-daily LWT classification).

705

Figure 3. Correlation between gridded CRU TS3.21 precipitation and seasonal cyclone metrics. White areas over land denote where correlations are insignificant $(p>0.05)$. Upper and lower correlation coefficients ( $r)$ given in each panel are the mean correlations for the whole domain $\left(36.25^{\circ} \mathrm{N}\right.$ to $69.75^{\circ} \mathrm{N}, 11.75^{\circ} \mathrm{W}$ to $\left.19.75^{\circ} \mathrm{E}\right)$ and $\mathrm{BI}$ only, respectively.

Figure 4. Seasonal variations in cyclone metrics for the BI. All 56 ensemble members' six-hourly time series of cyclone counts and intensity were convolved with a 31-day window (with weights equal to the reciprocal of window length). This converts counts to a probability of at least one cyclone being present in the BI domain for the respective time of the year. Storminess was calculated from these smoothed series, expressed as units of probability-weighted intensity; cyclone intensity is in units of Laplacians of sea-level pressure. Smoothed series were averaged over all ensemble members and 142 years (i.e. 1871-2012) to generate the seasonal profiles. Shaded areas denote \pm one standard error of the mean; tick marks indicate the beginning of a month.

Figure 5. Mean cyclone counts by season. Bars denote \pm one standard error in the ensemble mean for 30-year blocks (except 1991-2012).

Figure 6. Annual cyclone metrics by season and full year. Solid lines show the ensemble mean and shaded regions span the range of the 56 ensemble members. Dotted lines are the 11-year moving average. Units of count are simply the number of centres detected in the six-hourly grids, whilst intensity and storminess have units of Laplacians of mean sea-level pressure.

Figure 7. Decadal mean cyclone statistics by season expressed as a z-score averaged over all $5620 \mathrm{CR}$ ensemble members. Error bars indicate \pm one standard deviation of the 56 decadal means. Numbers above/below the bars give the rank of the decade for the respective metric and season.

723 Figure 8. Composite standardized anomalies (z-scores) in the $500 \mathrm{hPa}$ geopotential height field for the years of exceptional 724 cyclone frequency (left) and intensity (right) (see Table 2). Grid cells with absolute $z$-scores less than 1 are white.

725 Figure 9. Correlation between blocking frequency (BITM) at each grid point and cyclone frequency (left) and intensity

726 (right) over the BI. Regions where the correlation is significantly different from zero at $p<0.05$ (according to a two-tailed $t$ 727 test) are coloured.

728 Figure 10. Left: Seasonal cycle of cyclone probability and blocking probability for the BI domain. The cyclone probability 729 curve is taken from Figure 4. The blocking curve is calculated via the same convolution procedure described in Figure 4 730 caption, and represents the probability of at least one grid cell being blocked in the BI domain. Right: Summer minus winter 731 blocking frequency (\%) across the North Atlantic region, averaged over the full length of the $20 \mathrm{CR}$. 

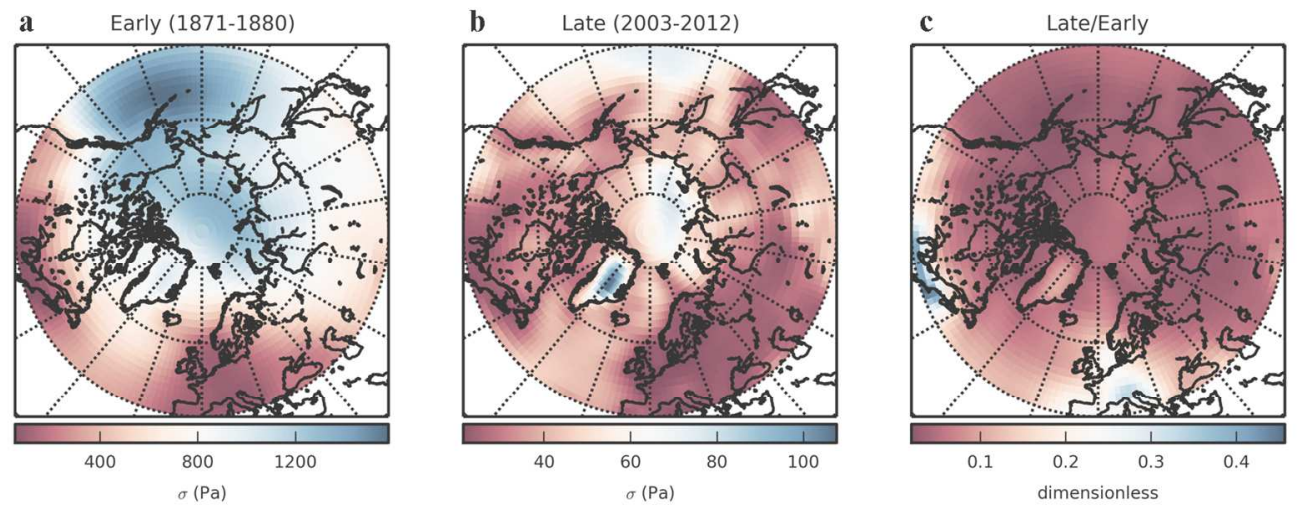

Panels $a$ and $b$ indicate the decadal mean standard deviation of daily-mean sea-level pressure amongst the 56 20CR ensemble members for the respective decades. To produce these fields, the standard deviation of the daily mean sea-level-pressure was calculated across the 56 ensemble members at each grid cell. Time averages for these fields were then calculated for each grid cell and respective decade. Panel c shows the data in the middle panel as a fraction of that plotted in a. The larger the fraction, the less uncertainty has changed with time implying greater homogeneity in those regions.

\section{$150 \times 61 \mathrm{~mm}(300 \times 300 \mathrm{DPI})$}



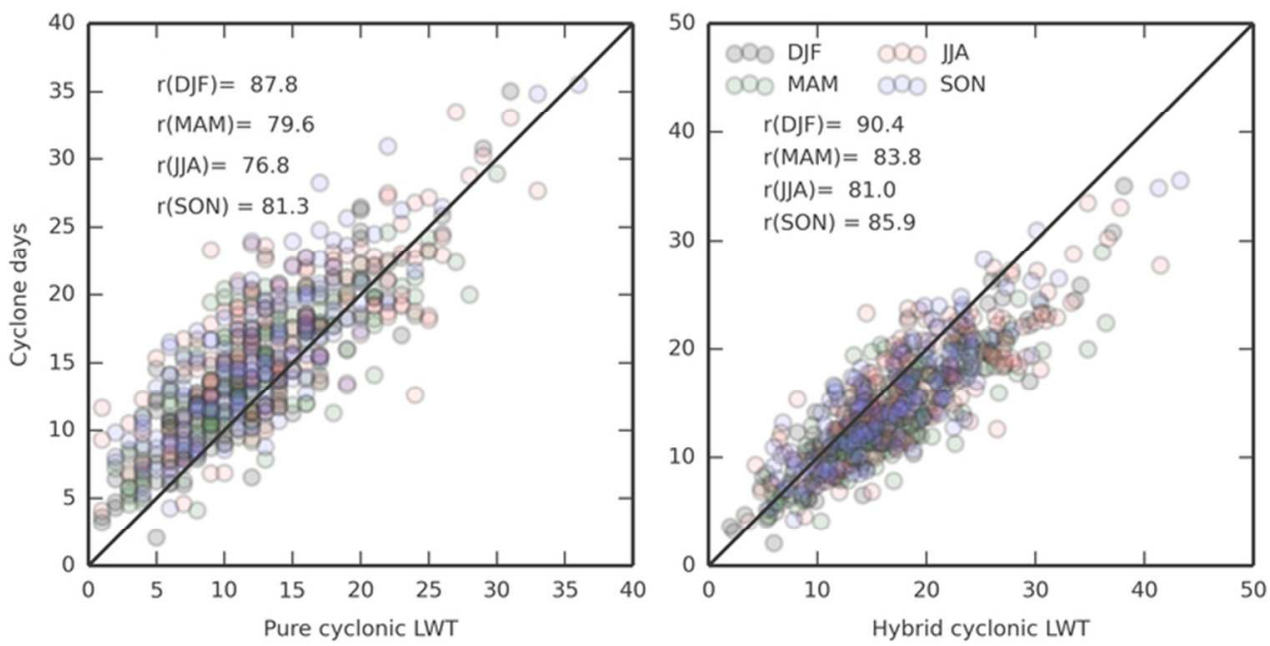

Relationship between 20CR cyclone counts and total pure (left) and hybrid (right) cyclonic LWTs. Seasonal correlation coefficients (multiplied by 100) between series are also shown. Solid black lines denote the 1:1 relationship. 'Cyclone days' is defined as the number of cyclones identified in the six-hourly grids, divided by 4 (to be consistent with the once-daily LWT classification).

$67 \times 36 \mathrm{~mm}(300 \times 300$ DPI $)$ 

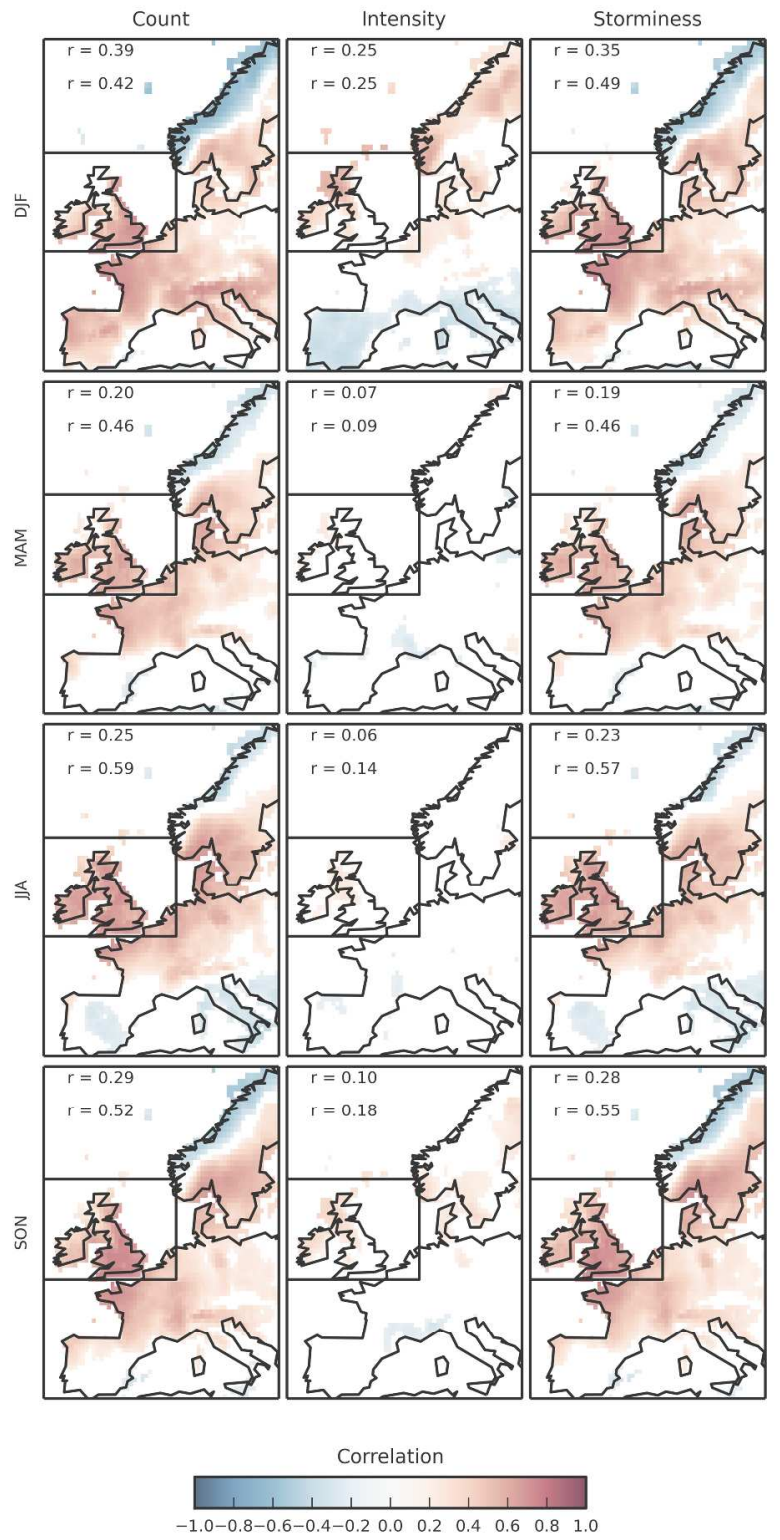

Correlation between gridded CRU TS3.21 precipitation and seasonal cyclone metrics. White areas over land denote where correlations are insignificant $(p>0.05)$. Upper and lower correlation coefficients $(r)$ given in each panel are the mean correlations for the whole domain $\left(36.25^{\circ} \mathrm{N}\right.$ to $69.75^{\circ} \mathrm{N}, 11.75^{\circ} \mathrm{W}$ to $19.75^{\circ} \mathrm{E}$ ) and BI only, respectively. $203 \times 406 \mathrm{~mm}(300 \times 300$ DPI $)$ 


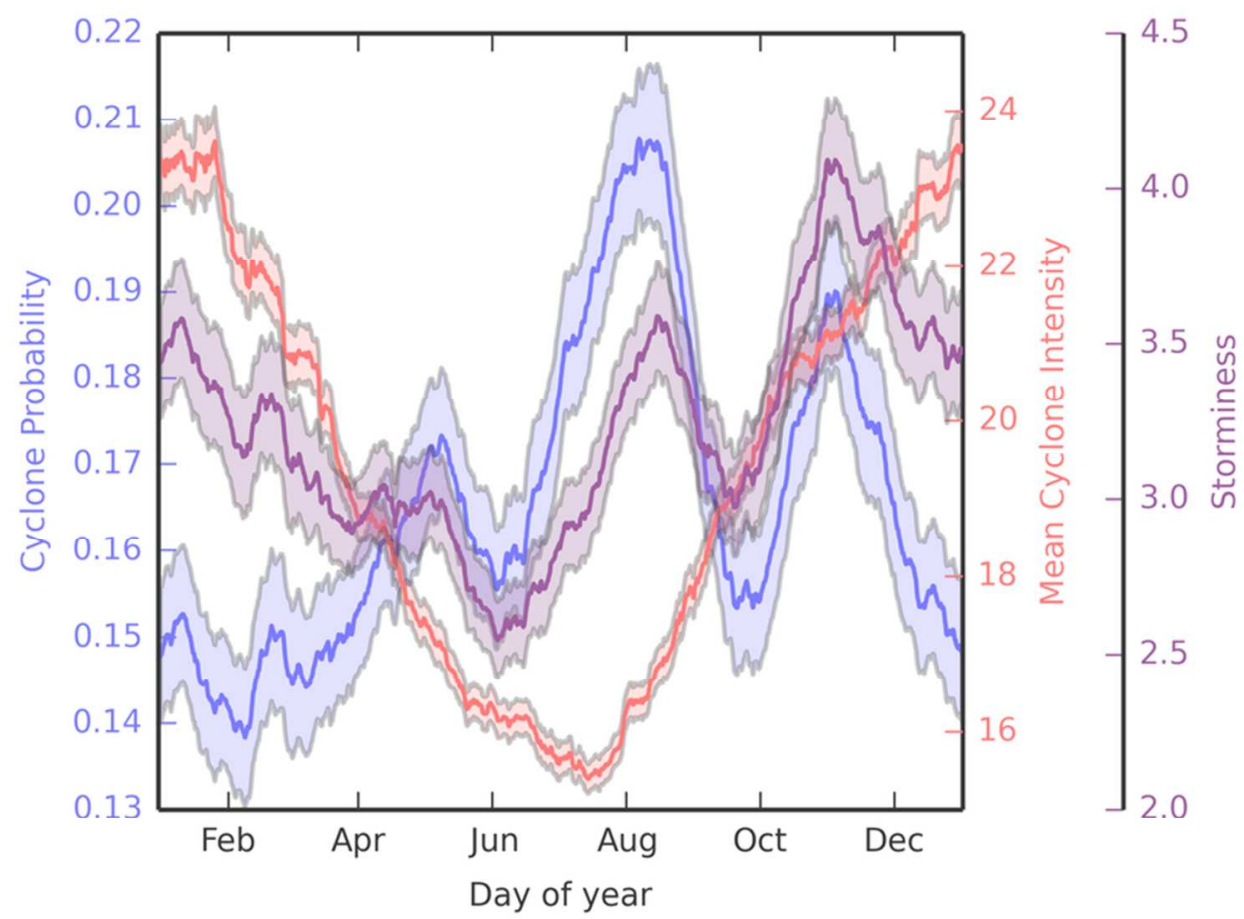

Seasonal variations in cyclone metrics for the BI. All 56 ensemble members' six-hourly time series of cyclone counts and intensity were convolved with a 31-day window (with weights equal to the reciprocal of window length). This converts counts to a probability of at least one cyclone being present in the BI domain for the respective time of the year. Storminess was calculated from these smoothed series, expressed as units of probability-weighted intensity; cyclone intensity is in units of Laplacians of sea-level pressure. Smoothed series were averaged over all ensemble members and 142 years (i.e. 1871-2012) to generate the seasonal profiles. Shaded areas denote \pm one standard error of the mean; tick marks indicate the beginning of a month.

$76 \times 57 \mathrm{~mm}(300 \times 300$ DPI $)$ 


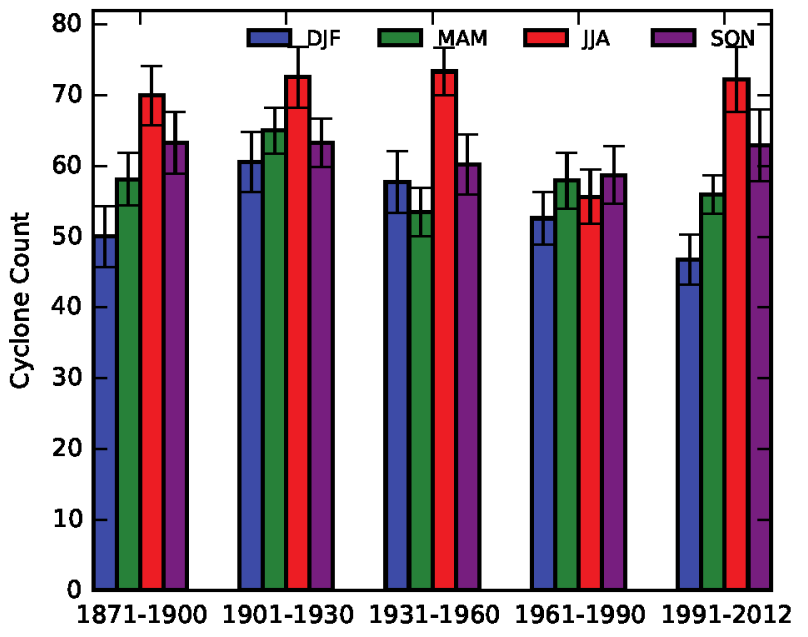

http://mc.manuscriptcentral.com/joc 

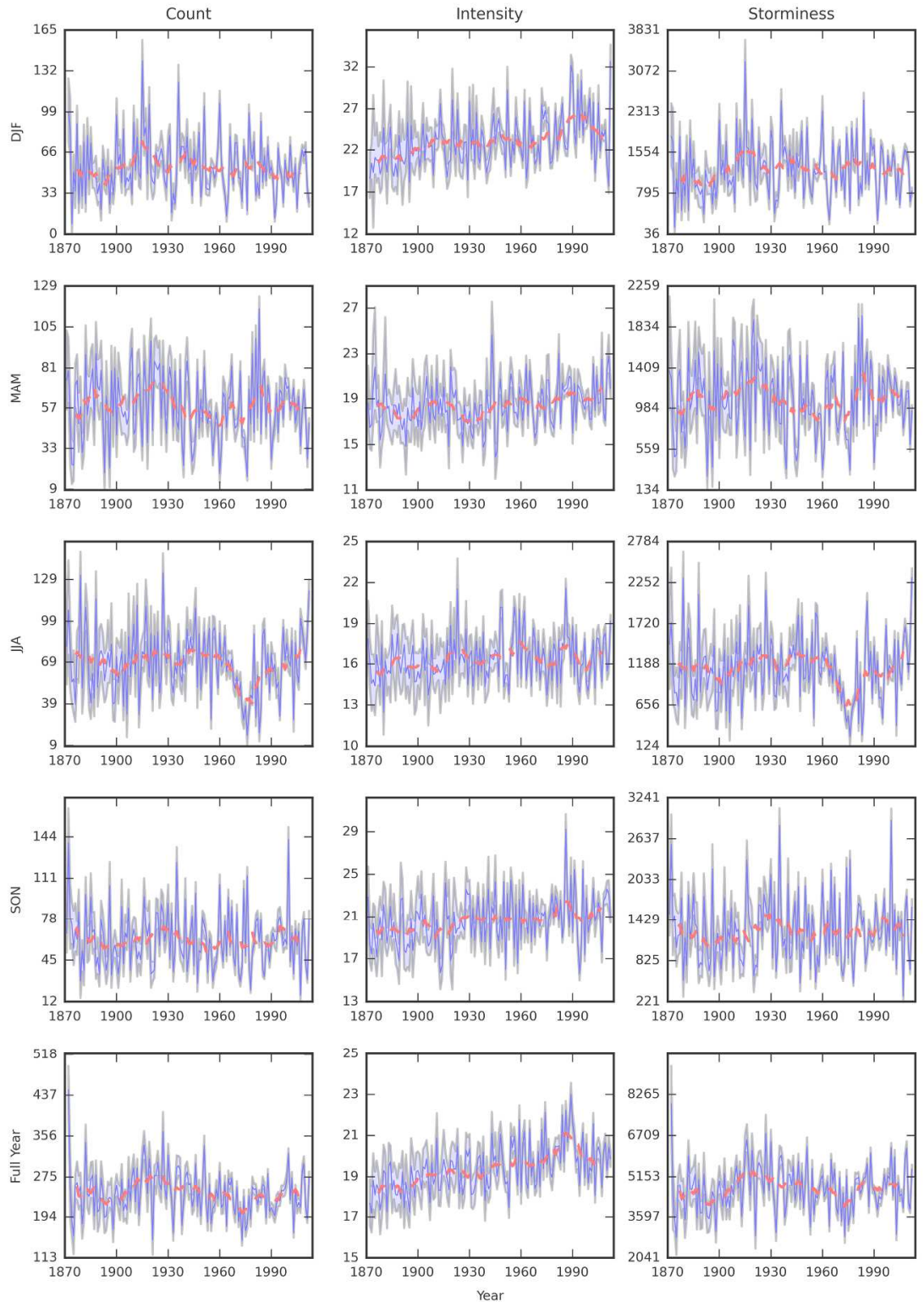

Annual cyclone metrics by season and full year. Solid lines show the ensemble mean and shaded regions span the range of the 56 ensemble members. Dotted lines are the 11-year moving average. Units of count are simply the number of centres detected in the six-hourly grids, whilst intensity and storminess have units of Laplacians of mean sea-level pressure. $215 \times 305 \mathrm{~mm}$ (300 x 300 DPI) 
Decadal mean cyclone statistics by season expressed as a z-score averaged over all $5620 \mathrm{CR}$ ensemble members. Error bars indicate \pm one standard deviation of the 56 decadal means. Numbers above/below the bars give the rank of the decade for the respective metric and season.

$$
215 \times 262 \mathrm{~mm}(300 \times 300 \mathrm{DPI})
$$



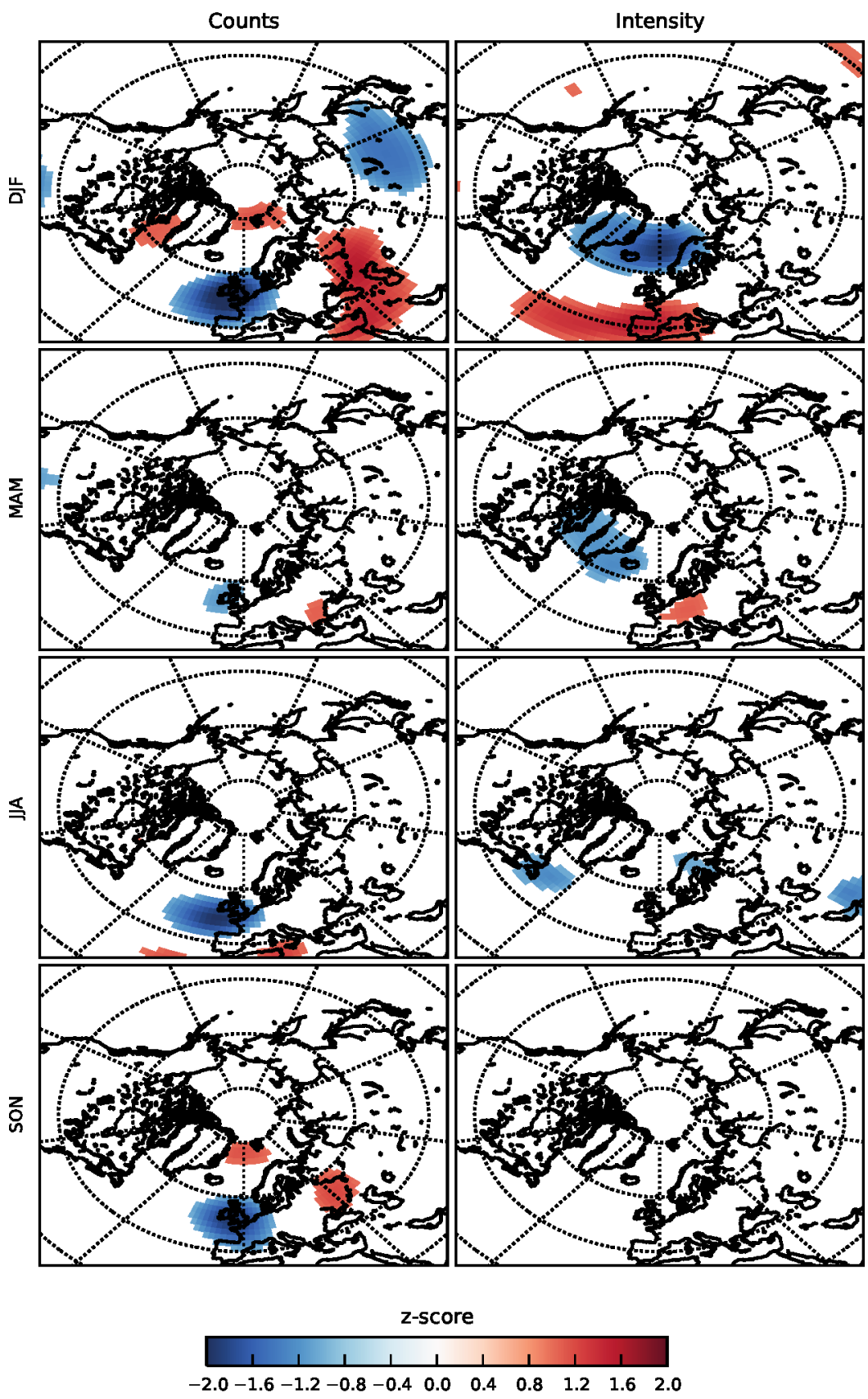


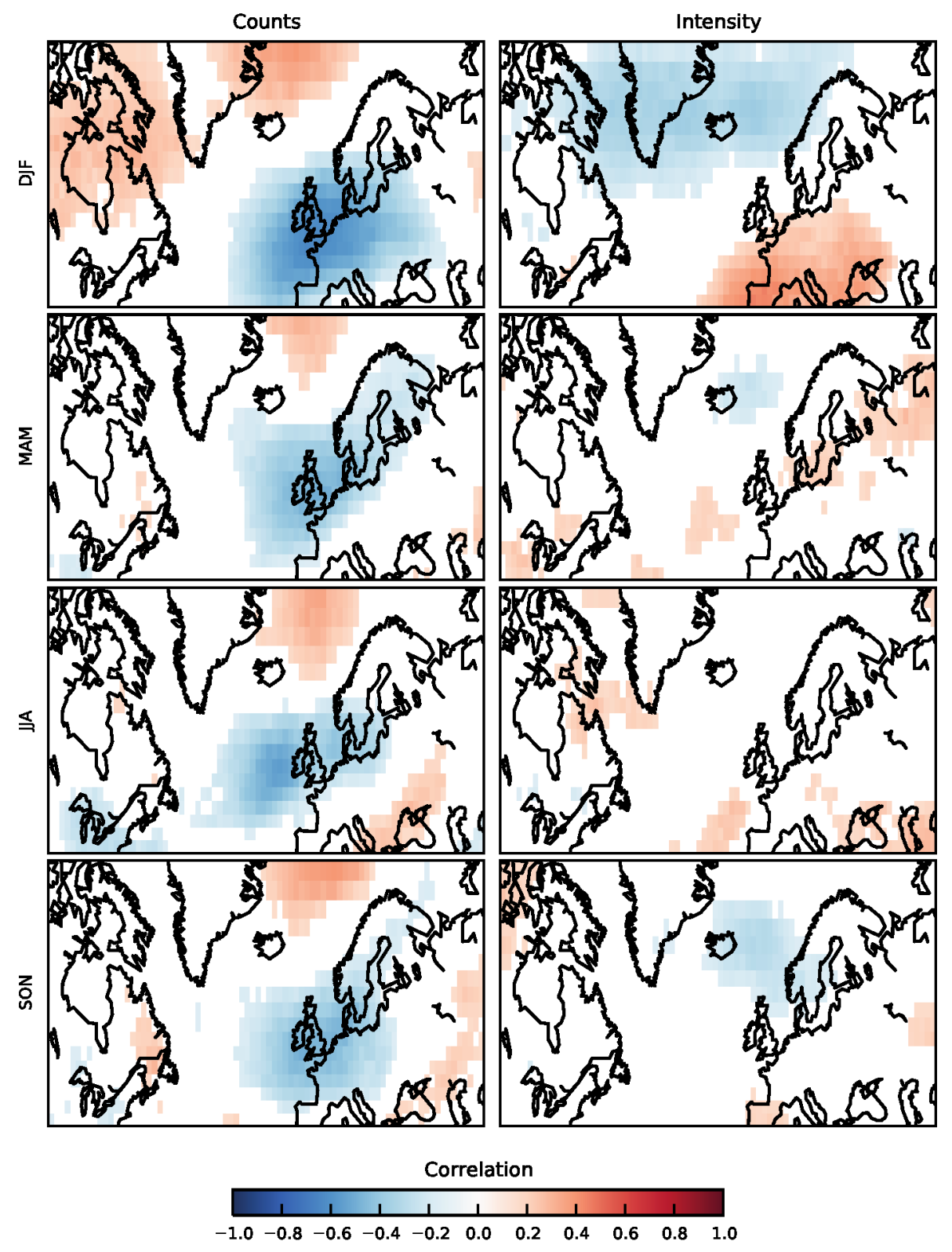

http://mc.manuscriptcentral.com/joc 

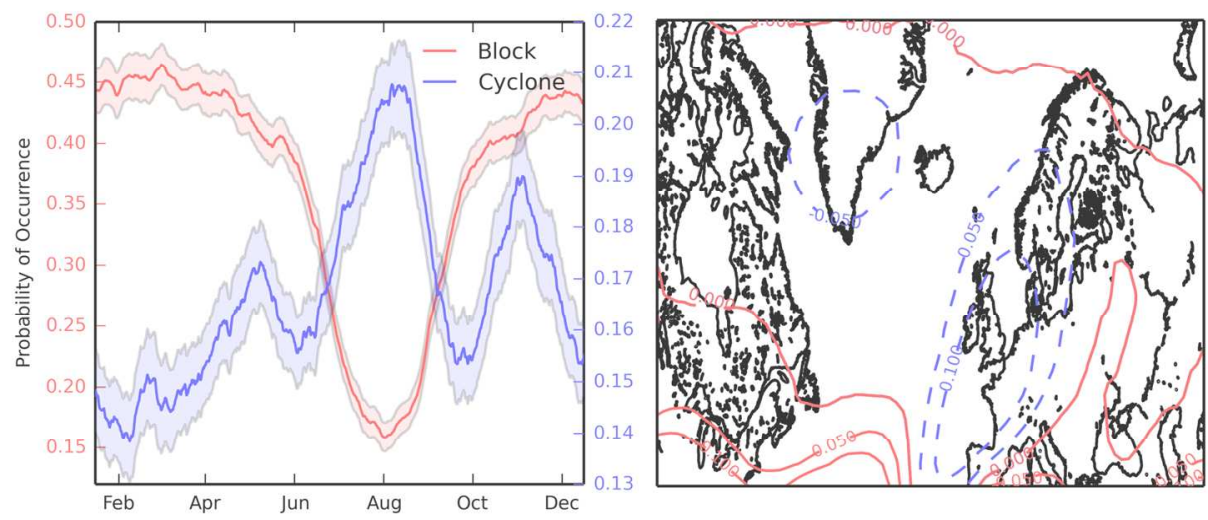

Seasonal cycle of cyclone probability and blocking probability for the BI domain. The cyclone probability curve is taken from Figure 4. The blocking curve is calculated via the same convolution procedure described in Figure 4 caption, and represents the probability of at least one grid cell being blocked in the BI domain. Right: Summer minus winter blocking frequency (\%) across the North Atlantic region, averaged over the full length of the 20CR. $163 \times 77 \mathrm{~mm}(300 \times 300 \mathrm{DPI})$ 